\title{
THE BALANCE BETWEEN SOCIAL LIFE AND WORK AND ITS RELATIONSHIP WITH WORK STRESS - AN APPLIED STUDY ON THE MINISTRY OF YOUTH AND SPORTS AFFAIRS IN THE KINGDOM OF BAHRAIN
}

\author{
Najwa Naseeb Saad Faraj ${ }^{1}$, Atheelah Al Azzawi ${ }^{2}$, Saad Darwish ${ }^{3}$, Horiya Al \\ Deeb $^{4}$ \\ ${ }^{1}$ West Riffa Secondary Girls School, Kingdom of Bahrain \\ ${ }^{2,4}$ Applied Science University (ASU), Kingdom of Bahrain \\ ${ }^{3}$ Kingdom University, Kingdom of Bahrain
}

\section{ABSTRACT}

The aim of this research is to identify the degree of the balance between social life and work and to measure the level of work stress of the employees of the Ministry of Youth and Sports Affairs in the Kingdom of Bahrain. One hundred employees were surveyed through a random stratified sample. The analysis is based on the outcomes of the questionnaire survey that was given out to a representative sample in the ministry. The researchers hypothesized that there is a significant relationship between the balance of social life, work, and work stress for the employees in the Ministry. Findings revealed the existence of work stress that resulted in work pressure. Employees see their commitment to the vocational rules contributed to improving their professional performance. Management considers the capabilities and skills of the employees when they are assigned to work on tasks.Based on findings, there are some recommendations, including the need for workshops and training sessions to help employees to overcome work stress and deal with multiple teams.

\section{KEYWORDS}

Social life and work, work stress, conflict, Kingdom of Bahrain

\section{INTRODUCTION}

A balance between social life and work is a recent concept that is introduced to society because of recent life dynamic nature. Family responsibilities have increased to a degree that impedes the social dimension for family life and affects its psychological situation. The importance of the balance between social life and work in due to caring for the individual peace and family protection from collapse. Recent civil life causes some problems related to the employee's life and work. These problems should be resolved rapidly through scrutinizing the concept of the balance between social life and work. Work pressure is considered as a barrier for professional development. It affects the health and psychological situation of the employee and then affects his professional performance and productivity at work negatively. The effects of work pressure have five consequences according to the literature. Behavioral such as addiction to painkillers, over eating and smoking, subjective as anxiety, aggression, indifference and lack of self-esteem,

DOI: $10.5121 /$ ijdkp.2019.9102 
cognitive as weak decision-making, weak focus and physiological as increased heartbeat and hypertension. Further organizational such as low productivity, high turnover rates, job dissatisfaction, and high absence rate and low loyalty. Here we tried to investigate and identify to what extent employees are able to balance between social life and work with the presence of work pressure relating to the case of the study.

The rest of this paper is organized as follows: Literature review is presented in section (2).Section (3) introduces the methodology. Discussion and results of statistical analysis are explained in section (4), while conclusions are in section (5).

\section{THEORITICAL FrAMEWORK AND LITERATURE REVIEW}

The statement is self-explanatory "The balance between social life and work" as it indicated creates tension and confusion for some people and makes them take the wrong path sometimes in dealing with issues. There are three models.

The first model is the traditional model, which is characterized by the fact that there are clear boarders between work and personal life. It considers work is separated from the individual's personal life and work duration is between 5-9 hours a day. According to this model, people don't undertake any work related to their work outside work place and people don't talk about any details related to work with any person outside the work place. It considers that people work for money, not more. Some people dislike their work and always are complaining and keep searching for other jobs to get a better salary. However, even when they get a new job with a higher salary, they start again to complain .People always feel stress in their work and feel happy when they leave their work. People show enthusiasm in their holidays (Maher, 2010, 88).

The second model considers most people do not see that work as separated from their personal life they have no borders between work and their personal lives. People work for long hours and take their work home to finish what they started at work. They work continuously and even on holidays. Some people when they leave work or go out for any social activity, they pass most of their time working on their personal computer and following their electronic mail. People love the technology dimension, and pass most of their time to complete their projects and they don't care about money. People are afraid of looking for a new job as they are interested in their work (Aldulaimi \& Abdeldayem, 2018, and ALbayatii, 2011, 97).

The third model is seen as the ideal model. According to this model, personal life is completely detached from work. There is always clear objectives in people's life and they realize money but also they like to live happily with family and friends. They look for the job they likeand their families and friends support them. They have a positive attitude towards everything in life (Maher, 2010, 88).They do not go to work only for money but also theylove work which has a positive on others .They try to add value and meaning to the world (ALbayatti, 2011, 113).

Table 1 : Definitions of balance between social life and work

\begin{tabular}{|l|l|l|}
\hline Serial & Author & Definition \\
\hline a & (Clark, 2001) & $\begin{array}{l}\text { Satisfaction in work and at home with minimum conflict } \\
\text { of roles. }\end{array}$ \\
\hline b & $\begin{array}{l}\text { (Kirchmeyer, } \\
2001)\end{array}$ & $\begin{array}{l}\text { Realizing satisfaction in all life domains and providing all } \\
\text { the required personal resources as effort, time and } \\
\text { commitment. }\end{array}$ \\
\hline
\end{tabular}




\begin{tabular}{|l|l|l|}
\hline c & (Hill, 2001) & $\begin{array}{l}\text { The extent that enables people to balance between the } \\
\text { temporary, emotional and behavior requirements for both } \\
\text { work and family responsibilities together. }\end{array}$ \\
\hline d & $\begin{array}{l}\text { (Kalliath \& } \\
\text { Brough, 2008) }\end{array}$ & $\begin{array}{l}\text { Balance between life and work is the persons' perception } \\
\text { for professional and non-professional activities which are } \\
\text { consistent and support growth according to the current } \\
\text { priorities of people's life. }\end{array}$ \\
\hline e & $\begin{array}{l}\text { (Voydanoff, } \\
\text { 2008) }\end{array}$ & $\begin{array}{l}\text { Balance between life and work is a universal evaluation } \\
\text { for family resources and working efficiently for meeting } \\
\text { work and family requirements. }\end{array}$ \\
\hline
\end{tabular}

\subsection{The IMPORTANCE OF THE BALANCE BETWEen SOCIAL LIFE AND WORK:}

The importance of the balance between social life and work lies in creating a healthy and preserved work environment (Aldulaimi and Abdeldayem, 2018). It enables employees to balance between their work and personal responsibilities, and it reinforces their work loyalty, so their productivity increases. Employees have many responsibilities, as their work, taking care of children, home works, and voluntary works and taking care of parents and old people. These responsibilities are considered as stress on persons, families and society. So, the conflict between life and work is a serious problem that affects employees, managers and society in general (Nesairat, 2010, 39). Some people see that balance between social life and work is impossible, others see that it can be applied for everyone for increasing productivity levels and incentives in work place. So, balance between life and work is considered as an inevitable issue that aims at separating social life from work to avoid stress and diseases like heart, diabetes diseases and alcohol addiction (Nesairat, 2010, 67).

\subsection{Factors Affecting The Balance Between Social Life AND Work:}

Economic changes like globalization and knowledge economics, a social and institutional changes such as health care, and difficulties in taking care or people of special needs, children and old people. Demographic characteristics such as one parent families and new generation.Changes in the organization's work by increasing the work stress, flexibility and remote work. Changes in the structure of the manpower and work structure relating to work stress because of increasing work lead and unsafe job (Abdeldayem, 2018 and Al Ghalbi, 2010, 163)

\subsection{Stages Of Developing Balance BetWeen Life ANd Work:}

- At the end of the nineteenth century, a balance between life and work started when reformers succeeded in a campaign against long work hours in the factories that affected workers outputs.

- At the beginning of the twentieth century, campaigns against long work hours continued giving attention to the importance of incentives, fatigue and concentration to discover the circumstances that encourage reducing worktime and increasing production.

- In 1970, there was a turning point as a result of many factors such as universal competitiveness, technology changes, new organizations, increase of women participation, perception of the importance of equality between men and women differentiation of needs during work time.

- In 1980, the concentration was on flexible work and reforming of the work market. 
- In 1990, the government interfered to provide employees with definite capabilities and rights relating to realizing the balance between personal life and work appropriately. Matching with the European Union Laws, The United Kingdom enacted laws that reflects the wish to realize the balance between the personal life and work such as motherhood and fatherhood rights, parent's rights and urgent cases holidays (Amer, 2011, 48).

\subsection{Aims Of The Balance Between Social Life And Work:}

Satisfaction of individual's needs that can be classified into four needs:

a. Physiological needs that aim at human survival as food, drink, residence, sleep and rest (Abdellatif, 2010,92).

b. Psychological needs that aim at psychological growth and prevention of psychological disorders as security, reassurance, self-reliance and achievement (Andraoes and Maaiaa, 2010, 112).

c. Social needs that aim at developing the relationship between men and others as love, appreciation and loyalty (Abdellatif, 2010, 101).

d. Spiritual needs that relates to the spiritual dimension of men as marriage, reproduction, honoring parents and connections with extended family members (Aqlah, 2010, 119).

\subsection{WORK STRESS:}

Work stress leads to the anxiety and emotion that affects the professional tasks and duties and also affects the individual's relations with other people working in the organization (Al Tamimi, 2011, 69).

Work stress leads to negative environmental factors such as ambiguity of role, roles conflict, bad work conditions and over burden (Al meshaan, 2010, 83).

\subsubsection{THE IMPORTANCE OF WORK STRESS STUDY:}

It is very important to study work stress as it leads to organizations' suffering from employees' absence, losing the desire for innovation, low motivation and low commitment. All this affects employee's performance and their end results (Ismail, 2012).

\subsubsection{WORK PRESSURE FACTORS:}

a. The stimulus which can result from the individual or the organizations or the environment.

b. Response as the physiological, psychological and behavioral reactions as anxiety tension and frustration.

c. The interaction between factors and respondents (Al Sabaie, 2010, 27).

\subsubsection{WORK STRESS SOURCES:}

a. The environment with its social, political, legal and economic changes.

b. Family, its expectation and the conflict between its requirements and work requirements. Also family's events as death and diseases (Al Qtaish, 2011,34).

c. Personal events that cause tension (Jooda, 2010,97)

d. The conflict between individual personality and work requirements (Bahar, 2010,60).

e. Personal relations disruption (AlQtaish. 2011,62). 
f. Work difficulty

g. The ambiguity of role (Ibrahim 2010, 45)

h. Role conflict

i. Work environment disruption as an inconvenient physical work environment (light, heat, humidity \& noise) lead to stress (Al Bader, 2010, 17)

\subsubsection{WORK STRESS EFFECTS:}

\section{First: The positive effects:}

a. Motivation

b. More focus on work results (Al Qahtani, 2011, 68)

c. Ability to express feelings and emotions.

d. Accomplishment, increase of trust and vitality. (Dodween, 2012, 56).

\section{Second: The negative effects:}

\section{Effects on individuals:}

a. Behavioral effects such as insomnia, over-smoking, anorexia, change in sleeping habits, ad use of sedative medications (Askar, 2010, 67).

b. Psychological effects such as sadness, frustration, anxiety, pessimism, difficult, forgetting and emotional imbalance.

c. Health effects such as headaches, ulcers, diabetes, blood pressure and heart diseases (Amer, 2011, 19).

\section{Effects on organization:}
a. Increase of costs
b. Lose productivity level and quality of work done.
c. Difficulty of concentration at work and more industrial accidents.
d. Low morale
e. Employee's dissatisfaction.
f. Absence
g. Delays
h. Increase of complaints and grievances.
i. Bad relations between employees.
j. Bad communication because of the ambiguity of roles
k. High turnover rate (Dodween, 2012,75).

\subsubsection{STRATEgies To DeAl With WORK STRESS}

\section{First: Strategies for individuals:}

a. Meditation is a way to train one's mind to work under pressure.

b. Relaxation, as the body rests this leads to mental comfort.

c. Focus, as it helps the individual to forget stress sources and concentrate to accomplish a distinguished work (Ghoneim, 2010,37)

d. Exercises, to increase the effectiveness of body parts to concentrate.

e. Friendship, encouragement and social cooperation help the individual to work under pressure. 
International Journal of Data Mining \& Knowledge Management Process (IJDKP) Vol.9, No.1, January 2019

f. Having clear, realistic and planned objectives for work, helps the individual to work under pressure (Asfoor, 2010, 28).

\section{Second: strategies for the organization:}

a. Good application for the principles of management to spread the managerial discipline (Al Sairafi, 2010, 46).

b. Redesigning the organizational chart to solve work stress problems as adding a new managerial level or merge of functions (Al Sairafi, 2010,33)

c. Organizational development through developing employees selection systems or redesigning training and performance evaluation systems (Al Shanty, 2010,41)

d. Precise section for roles requirements to prevent roles conflict.

e. Physical environment organizing to make the work easy and reduce risk.

f. Treatment systems to reduce work stress as appointing a psychologist and customizing rooms for exercises (Al Sakarn, 2010,68)

\section{Study Methodology}

\subsection{ReSEARCH Problem:}

Work stress is considered one of the managerial diseases that negatively affect the employees. It resulted from roles conflicts, the nature of work and work environment as work responsibilities interference with social ones resulting in more stress and exhaustion. The solution to this problem is trying to balance social life and work. So, the problem of this research is phrased through the answer to the following questions:

$\checkmark$ What is the level of balance between social life and stress for the employees in the Ministry of Youth and Sports Affairs in the Kingdom of Bahrain? According to the opinions of the employees there.

\subsection{IMPORTANCE OF THE RESEARCH:}

The balance between social life and work is considered animportant and recent topic in the Arab world (Abdeldayem and Aldulaimi, 2018). Also, the Ministry of Youth and Sports Affairs in the Kingdom of Bahrain is considered as one of the most important associations that care about youth projects and achievements in all fields. Employees have many responsibilities and stress, so this research aims to identify the reasons of work stress and its reflection on employees in the Ministry of Youth and Sports Affairs in the Kingdom of Bahrain in order to avoid this problem though the activation of the balance between social life and work.

\subsection{RESEARCH OBJECTIVES:}

a. To identify the extent of balance between social life and work for employees of the Ministry of Youth and Sports Affairs in the Kingdom of Bahrain.

b. To measure the level of work stress for employees in the Ministry of youth and Sports Affairs in the Kingdom of Bahrain.

c. To identify the relationship between the balance of social life and work and its reflections on the work stress of the employees of the Ministry of Youth and Sports Affairs in the Kingdom of Bahrain.

d. Introducing recommendations in light of the results of the research. 
International Journal of Data Mining \& Knowledge Management Process (IJDKP) Vol.9, No.1, January 2019

\subsection{RESEARCH HYPOTHESES:}

\section{Main hypotheses 1:}

H1: There is a significant relationship between the balance of social life and work, and work stress for the employees in the Ministry of Youth and Sports Affairs in the Kingdom of Bahrain.

\section{Subsidiary hypotheses 1:}

H1: There is a significant relationship between the personal and social dimension for the balance between social life and work, and work stress for the employees of the Ministry of Youth and Sports Affairs in the Kingdom of Bahrain.

\section{Subsidiary hypotheses 2:}

H1: There is a significant relationship between the psychological and behavioral dimension for the balance between social life and work, and work stress for the employees in the Ministry of Youth and Sports Affairs in the Kingdom of Bahrain.

\section{Subsidiary hypothesis 3:}

H1: There is a significant relationship between the professional dimension for the balance between social life and work, and work stress for the employees in the Ministry of Youth and Sports Affairs in the Kingdom of Bahrain.

\section{Subsidiary hypotheses 4:}

H1: There is a significant relationship between the economic dimension for the balance between social life and work, and work stress for the employees of the Ministry of Youth and Sports Affairs in the Kingdom of Bahrain.

\section{Main Hypothesis 2:}

H1: There are significant differences between the balance between social life and work, and work stress due to the demographic characteristics (Gender, age, qualification, years of experience, training courses) for the employees of the Ministry of Youth and Sports Affairs in the Kingdom of Bahrain 


\subsection{RESEARCH FRAMEWORK:}

Figure 1: Research framework

Independent Variable

\begin{tabular}{l} 
Balance between social life and \\
work: \\
- Personal and social \\
dimension \\
- Psychological and \\
- behavioral dimension \\
- Professional dimension \\
\hline
\end{tabular}

Dependent Variable

\section{Work Stress:}

- Work environment

- The nature of work

- Roles conflicts

Ministry of Youth

and Sports Affairs,

Bahrain

\section{Demographics}

Gender, age, qualification, years of

experience, training courses.

\subsection{Population And SAmple Of The ReSEarch:}

Employees of the Ministry of Youth and Sports Affairs in the Kingdom of Bahrain (230) are considered as the research population, and a random stratified sample (100) was selected. The sample provided information through filling a questionnaire which is considered the core of data for this research.

\subsection{Data Collection:}

A five-point Likert Scale was used to collect the questionnaire survey as follows:

\begin{tabular}{|c|c|c|c|c|}
\hline 5 & 4 & 3 & 2 & 1 \\
\hline Strongly Agree & Agree & Neutral & Disagree & Strongly Disagree \\
\hline
\end{tabular}

A number of 120 questionnaires were circulated and a total of 110 were collected. Ten of them were in complete, so we discarded them. One hundred were considered with a response of $91.7 \%$ 


\section{RESEARCH FINDINGS AND RESULTS:}

Statistical results of Pearson correlation are as follows:

Table 2 : Pearson correlation co-efficient

\begin{tabular}{|l|l|l|l|l|l|l|l|}
\hline Statement & $\begin{array}{l}\text { Correlation } \\
\text { coefficient }\end{array}$ & Statement & $\begin{array}{l}\text { Correlation } \\
\text { coefficient }\end{array}$ & Statement & $\begin{array}{l}\text { Correlation } \\
\text { coefficient }\end{array}$ & Statement & $\begin{array}{l}\text { Correlation } \\
\text { coefficient }\end{array}$ \\
\hline 1 & 0.546 & 14 & 0.418 & 27 & 0.652 & 40 & 0.654 \\
\hline 2 & 0.411 & 15 & 0.65 & 28 & 0.387 & 41 & 0.549 \\
\hline 3 & 0.611 & 16 & 0.634 & 29 & 0.704 & 42 & 0.657 \\
\hline 4 & 0.566 & 17 & 0.567 & 30 & 0.544 & 43 & 0.654 \\
\hline 5 & 0.723 & 18 & 0.657 & 31 & 0.704 & 44 & 0.669 \\
\hline 6 & 0.649 & 19 & 0.623 & 32 & 0.544 & 45 & 0.533 \\
\hline 7 & 0.687 & 20 & 0.514 & 33 & 0.784 & 46 & 0.597 \\
\hline 8 & 0.724 & 21 & 0.418 & 34 & 0.647 & 47 & 0.562 \\
\hline 9 & 0.719 & 22 & 0.399 & 35 & 0.429 & 48 & 0.471 \\
\hline 10 & 0.64 & 23 & 0.476 & 36 & 0.574 & 49 & 0.437 \\
\hline 11 & 0.658 & 24 & 0.7 & 37 & & & \\
\hline 12 & 0.511 & 25 & 0.418 & 38 & & & \\
\hline 13 & 0.724 & 26 & 0.388 & 39 & & & \\
\hline
\end{tabular}

Table (2) shows that all correlation coefficients are significant at the level (0.01) which indicates that validity of the scale.

\section{Reliability}

The data were analyzed using SPSS and statistical results of Cronbach Alpha are as follow:

Table 3 : Cronbach Alpha

\begin{tabular}{|c|c|c|}
\hline \multicolumn{3}{|c|}{ Reliability Statistics } \\
\hline Dimensions & No. of statements & Cronbach's Alpha \\
\hline $\begin{array}{c}\text { The balance between } \\
\text { social life and work }\end{array}$ & 27 & 0.929 \\
\hline Work stress & 22 & 0.823 \\
\hline
\end{tabular}

Table (3) shows that the Cronbach's Alpha is 0.876 . This result indicates a high level of internal consistency for the research questionnaire with this specific sample which confirms that the measurements used in this research indicate a high level of internal consistency for the research questionnaire. 
International Journal of Data Mining \& Knowledge Management Process (IJDKP) Vol.9, No.1, January 2019

Table 4 : Balance between social life and work

\begin{tabular}{|c|c|c|c|c|c|c|c|c|c|}
\hline Sr & Statement & SA & $\mathbf{A}$ & $\mathbf{N}$ & $\begin{array}{l}\mathbf{D} \\
\mathbf{A}\end{array}$ & $\begin{array}{l}\text { SD } \\
\text { A }\end{array}$ & Mean & $\begin{array}{l}\text { Std } \\
\text { Devia } \\
\text { tion }\end{array}$ & $\begin{array}{l}\text { Coefficient of } \\
\text { Variation }\end{array}$ \\
\hline 1 & $\begin{array}{l}\text { Your family members have specific } \\
\text { responsibilities }\end{array}$ & 82 & 14 & & 3 & 1 & 3.501 & 0.946 & 0.27 \\
\hline 2 & $\begin{array}{l}\text { There is no overlap between your } \\
\text { family and life }\end{array}$ & 78 & 17 & & 5 & & 3.222 & 0.943 & 0.29 \\
\hline 3 & $\begin{array}{l}\text { There is a harmony between the } \\
\text { members of your family because they } \\
\text { are highly cultured }\end{array}$ & 80 & 15 & 5 & & & 3.303 & 0.941 & 0.28 \\
\hline 4 & $\begin{array}{l}\text { You always balance between your } \\
\text { work and social relations }\end{array}$ & 78 & 10 & & 2 & 6 & 2.521 & 0.945 & 0.37 \\
\hline 5 & $\begin{array}{l}\text { All your decisions reflect the } \\
\text { philosophy of balance between life } \\
\text { and work }\end{array}$ & 70 & 20 & 8 & 2 & & 2.621 & 0.916 & 0.34 \\
\hline 6 & $\begin{array}{l}\text { Your family members are interested } \\
\text { in sports that keep them healthy }\end{array}$ & 75 & 20 & 5 & & & 2.301 & 0.917 & 0.39 \\
\hline 7 & $\begin{array}{l}\text { Your family often organizes joumeys } \\
\text { for self-recreation }\end{array}$ & 73 & 17 & 8 & 2 & & 2.106 & 0.919 & 0.43 \\
\hline 8 & You are able to bear work pressure & 85 & 13 & 2 & & & 2.734 & 0.929 & 0.33 \\
\hline 9 & $\begin{array}{l}\text { Your work pressure doesn't affect } \\
\text { your psychological situation }\end{array}$ & 81 & 12 & 5 & 2 & & 2.814 & 0.932 & 0.33 \\
\hline 10 & $\begin{array}{l}\text { Frequently, you don't allow your } \\
\text { work to affect the quality of your } \\
\text { family life }\end{array}$ & 79 & 11 & 9 & 1 & & 3.269 & 0.932 & 0.28 \\
\hline 11 & $\begin{array}{l}\text { Your work environment is consistent } \\
\text { with your luxury style }\end{array}$ & 78 & 14 & 7 & 1 & & 3.312 & 0.937 & 0.28 \\
\hline 12 & $\begin{array}{l}\text { Your life requirements don't affect } \\
\text { your luxury practices }\end{array}$ & 82 & 16 & 2 & & & 3.315 & 0.949 & 0.29 \\
\hline 13 & $\begin{array}{l}\text { Your social life requirements affect } \\
\text { your morale in work and life }\end{array}$ & 69 & 18 & & 12 & & 3.277 & 0.952 & 0.29 \\
\hline 14 & $\begin{array}{l}\text { Employees in your department are } \\
\text { keen first for the sake of work }\end{array}$ & 79 & 11 & 9 & 1 & & 2.951 & 0.907 & 0.31 \\
\hline 15 & $\begin{array}{l}\text { Frequently, your work doesn't affect } \\
\text { your main life requirements }\end{array}$ & 78 & 14 & 7 & 1 & & 2.489 & 0.903 & 0.28 \\
\hline 16 & $\begin{array}{l}\text { The increase of work burden is } \\
\text { reflected on resignations in your } \\
\text { department }\end{array}$ & 82 & 16 & 2 & & & 3.162 & 0.91 & 0.29 \\
\hline 17 & $\begin{array}{l}\text { The increase of work burden is } \\
\text { reflected on the increase of mobility } \\
\text { of jobs in your department }\end{array}$ & 75 & 15 & & 5 & 5 & 3.117 & 0.987 & 0.32 \\
\hline 18 & $\begin{array}{l}\text { Long working hours doesn't affect } \\
\text { your professional performance } \\
\text { negatively }\end{array}$ & 76 & 18 & 6 & & & 2.841 & 0.912 & 0.32 \\
\hline 19 & $\begin{array}{l}\text { The increase of your colleagues } \\
\text { absence doesn't affect your } \\
\text { professional performance }\end{array}$ & 83 & 12 & 5 & & & 2.954 & 0.965 & 0.29 \\
\hline 20 & $\begin{array}{l}\text { The delay of the employees in your } \\
\text { department for their professional } \\
\text { performance doesn't affect your } \\
\text { professional efficiency }\end{array}$ & 81 & 12 & 5 & 2 & & 2.847 & 0.937 & 0.31 \\
\hline
\end{tabular}




\begin{tabular}{|l|l|l|l|l|l|l|l|l|l|}
\hline 21 & $\begin{array}{l}\text { Your commitment to your work rules } \\
\text { improves your professional } \\
\text { performance }\end{array}$ & 79 & 11 & 9 & 1 & & 2.741 & 0.957 & 0.29 \\
\hline 22 & $\begin{array}{l}\text { Your salary is equal to the salaries of } \\
\text { other employees in other } \\
\text { departments in the ministry }\end{array}$ & 84 & 14 & 2 & & & 3.254 & 1.026 & 0.31 \\
\hline 23 & $\begin{array}{l}\text { You are satisfied about the equality } \\
\text { of promotions between the } \\
\text { employees of your department }\end{array}$ & 70 & 10 & 20 & & & 2.654 & 1.024 & 0.38 \\
\hline 24 & $\begin{array}{l}\text { The rewards you take are equal to } \\
\text { the efforts you make }\end{array}$ & 73 & 15 & 9 & 3 & & 2.749 & 1.025 & 0.36 \\
\hline 25 & $\begin{array}{l}\text { Incentives and rewards are related to } \\
\text { the evaluation of your professional } \\
\text { performance }\end{array}$ & 74 & 16 & 8 & 2 & & 2.365 & 1.027 & 0.43 \\
\hline 26 & $\begin{array}{l}\text { According to your annual } \\
\text { performance evaluation, you seek to } \\
\text { provide the requirements for your } \\
\text { promoter }\end{array}$ & 68 & 20 & 10 & 2 & & 2.874 & 1.023 & 0.35 \\
\hline 27 & $\begin{array}{l}\text { Your performance evaluation is done } \\
\text { according to clear scientific criteria }\end{array}$ & 71 & 19 & 10 & & & 2.78 & 1.006 & 0.32 \\
\hline Total & & & & & & & & & \\
\hline
\end{tabular}

According to table (4) that shows that the mean for the balance between social life and work was (3.1875) with a standard deviation (1.3175) and coefficient of variation (0.27-0.43) for the employees of the Ministry of Youth and Sports Affairs in the Kingdom of Bahrain, the results around the balance between social life and work was average.

\section{Analysis of sample answers to the questionnaire dimension of work stress}

Table 5 : Work stress

\begin{tabular}{|l|l|l|l|l|l|l|l|l|l|}
\hline Sr. & Statement & SA & $\mathbf{A}$ & $\mathbf{N}$ & $\mathbf{D A}$ & $\mathbf{S D A}$ & $\mathbf{M e a n}$ & $\begin{array}{l}\text { Standard } \\
\text { Deviation }\end{array}$ & $\begin{array}{l}\text { Coefficient } \\
\text { of } \\
\text { Variation }\end{array}$ \\
\hline 28 & Work environment & 70 & 80 & 8 & 2 & & 2.654 & 1.008 & 0.27 \\
\hline 29 & $\begin{array}{l}\text { Work environment does not help } \\
\text { you to do your work easily }\end{array}$ & 75 & 20 & 5 & & & 2.65 & 1.009 & 0.26 \\
\hline 30 & $\begin{array}{l}\text { Not all the suitable tools you need } \\
\text { for your work re available }\end{array}$ & 73 & 17 & 8 & 2 & & 2.365 & 1.016 & 0.29 \\
\hline 31 & $\begin{array}{l}\text { Light is not enough at work } \\
\text { environment }\end{array}$ & 82 & 13 & 5 & & & 2.36 & 1.014 & 0.27 \\
\hline 32 & $\begin{array}{l}\text { You feel there is noise that hinders } \\
\text { work at work environment }\end{array}$ & 73 & 15 & 9 & 3 & & 1.011 & 1.017 & 0.32 \\
\hline 33 & $\begin{array}{l}\text { You feel very hot at work } \\
\text { environment }\end{array}$ & 74 & 16 & 8 & 2 & & 1.009 & 0.849 & 0.26 \\
\hline 34 & $\begin{array}{l}\text { You suffer from narrow space at } \\
\text { the work environment }\end{array}$ & 68 & 20 & 10 & 2 & & 1.005 & 1.003 & 0.31 \\
\hline 35 & $\begin{array}{l}\text { You suffer from crowing at work } \\
\text { environment }\end{array}$ & 70 & 20 & 8 & 2 & & 1.003 & 0.894 & 0.32 \\
\hline 36 & $\begin{array}{l}\text { Work load doesn't suit your } \\
\text { capabilities }\end{array}$ & 84 & 14 & 2 & & & 1.002 & 1.011 & 0.34 \\
\hline
\end{tabular}


International Journal of Data Mining \& Knowledge Management Process (IJDKP) Vol.9, No.1, January 2019

\begin{tabular}{|l|l|l|l|l|l|l|l|l|l|}
\hline 36 & $\begin{array}{l}\text { Work load doesn't suit your } \\
\text { capabilities }\end{array}$ & 84 & 14 & 2 & & & 1.002 & 1.011 & 0.34 \\
\hline 37 & $\begin{array}{l}\text { You often accomplish any extra } \\
\text { work on line }\end{array}$ & 70 & 10 & 20 & & & 1.001 & 1.019 & 0.36 \\
\hline 38 & $\begin{array}{l}\text { Management asks you to do some } \\
\text { work that is not suiting your } \\
\text { qualifications }\end{array}$ & 74 & 16 & 8 & 2 & & 0.894 & 1.034 & 0.39 \\
\hline 39 & $\begin{array}{l}\text { Management asks you to do some } \\
\text { work that is not suiting your } \\
\text { capabilities }\end{array}$ & 70 & 20 & 8 & 2 & & 0.891 & 1.047 & 0.36 \\
\hline 40 & You plan before you do your work & 75 & 20 & 5 & & & 0.888 & 1.045 & 0.44 \\
\hline 41 & $\begin{array}{l}\text { There is a control for your } \\
\text { professional performance to assure } \\
\text { quality }\end{array}$ & 73 & 17 & 8 & 2 & & 0.849 & 1.05 & 0.37 \\
\hline 42 & $\begin{array}{l}\text { You correct your mistakes during } \\
\text { working }\end{array}$ & 82 & 13 & 5 & & & 0.845 & 1.077 & 0.45 \\
\hline 43 & $\begin{array}{l}\text { You accomplish your specific tasks } \\
\text { with high performance }\end{array}$ & 73 & 15 & 9 & 3 & & 0.84 & 1.071 & 0.36 \\
\hline 44 & $\begin{array}{l}\text { You often arrange your works } \\
\text { according to their importance }\end{array}$ & 74 & 16 & 8 & 2 & & 2.654 & 1.073 & 0.37 \\
\hline 45 & You deal with more than work team & 68 & 20 & 10 & 2 & & 2.65 & 1.002 & 0.3 \\
\hline 46 & $\begin{array}{l}\text { You get instructions from more } \\
\text { than one responsible party }\end{array}$ & 70 & 20 & 8 & 2 & & 2.365 & 1.007 & 0.27 \\
\hline 47 & $\begin{array}{l}\text { You have to accomplish works } \\
\text { against your principles }\end{array}$ & 84 & 14 & 2 & & & 2.36 & 1.009 & 0.29 \\
\hline 48 & $\begin{array}{l}\text { Others expect from you what you } \\
\text { don't expect from yourself }\end{array}$ & 70 & 10 & 20 & & & 1.011 & 1.007 & 0.28 \\
\hline 49 & $\begin{array}{l}\text { Your success at work is at the } \\
\text { expense of your family and social } \\
\text { life }\end{array}$ & 73 & 15 & 9 & 3 & & 1.009 & 1.005 & 0.31 \\
\hline Total & & & & & & & & & \\
\hline & & & & & & & & & \\
\hline
\end{tabular}

According to Table (5) shows that the mean around work stress was (3.5466) with a standard deviation (1.4233) and a coefficient of variation (0.26-0.45), the result around the work stress was (high).

Table 6 : Means and standard deviations for sample answers for the variables of the balance between social

\begin{tabular}{|l|l|l|l|l|l|l|}
\cline { 2 - 7 } \multicolumn{9}{|c|}{ Independent Variable } & \multicolumn{2}{l|}{ life and work } \\
\hline Sr. & $\begin{array}{l}\text { The balance between } \\
\text { Social life and work }\end{array}$ & $\begin{array}{l}\text { No of } \\
\text { sample } \\
\text { members }\end{array}$ & Mean & $\begin{array}{l}\text { Standard } \\
\text { deviation }\end{array}$ & Rank & Classification \\
\hline 1 & $\begin{array}{l}\text { Personal and social } \\
\text { dimension }\end{array}$ & 100 & 3.19 & 1.36 & 3 & Medium \\
\hline 2 & $\begin{array}{l}\text { Psychological and } \\
\text { behavioral dimension }\end{array}$ & 100 & 3.16 & 1.23 & 1 & Medium \\
\hline 3 & Professional dimension & 100 & 3.18 & 1.25 & 2 & Medium \\
\hline 4 & Economic dimension & 100 & 3.22 & 1.43 & 4 & Medium \\
\hline
\end{tabular}


International Journal of Data Mining \& Knowledge Management Process (IJDKP) Vol.9, No.1, January 2019

Table 7 : Means and standard deviations for sample answers for the variables of work stress

\begin{tabular}{|c|c|c|c|c|c|c|}
\hline & Dependent Variable & & & & & \\
\hline Sr. & $\begin{array}{l}\text { The balance between } \\
\text { social life and work }\end{array}$ & $\begin{array}{l}\text { No of } \\
\text { sample } \\
\text { members }\end{array}$ & Mean & $\begin{array}{l}\text { Standard } \\
\text { deviation }\end{array}$ & Rank & Classification \\
\hline 1 & Work environment & 100 & 3.49 & 1.55 & 1 & Medium \\
\hline 2 & Work nature & 100 & 3.61 & 1.33 & 1 & Medium \\
\hline 3 & Role conflict & 100 & 3.54 & 1.39 & 2 & Medium \\
\hline
\end{tabular}

Table 8. Means and standard deviations for sample answers for the variables the balance between social life and work, and work stress

\begin{tabular}{|c|c|c|c|}
\hline Variables & $\begin{array}{c}\text { No. of sample } \\
\text { members }\end{array}$ & Mean & $\begin{array}{c}\text { Std. } \\
\text { Deviation }\end{array}$ \\
\hline $\begin{array}{c}\text { Independent variable: } \\
\text { The balance between social life and work }\end{array}$ & 100 & 3.1875 & 1.3175 \\
\hline $\begin{array}{c}\text { Dependent variable: } \\
\text { Work stress }\end{array}$ & 100 & 3.5466 & 1.4233 \\
\hline
\end{tabular}

Table (8) shows that the Ministry of Youth of Sports Affairs in the Kingdom of Bahrain apply the balance between social life and work, and work stress with "Medium".

\section{Testing hypotheses}

To make sure that main hypothesis 1 is correct, "There is a significant relationship between the balance of social life and work, and work stress for the employees in the Ministry of Youth and Sports Affairs in the Kingdom of Bahrain", the Pearson coefficients were calculated for sample answers for the questionnaire of the balance between social life and work and for the questionnaire of work stress as shown in the following table:

Table 9: The relation between the balance between social life and work, and work stress

\begin{tabular}{|c|c|c|c|}
\hline \multicolumn{2}{|c|}{ Variables } & $\begin{array}{c}\text { Balance between } \\
\text { social life and work }\end{array}$ & Work stress \\
\hline $\begin{array}{c}\text { The balance } \\
\text { between social life } \\
\text { and work }\end{array}$ & Pearson coefficient & & $0.398^{* *}$ \\
\hline Work stress & Pearson coefficient & $0.398^{* *}$ & \\
\hline
\end{tabular}

Table (9) shows that the value of the correlation between the balance social life and work, and work stress was (0.398) that indicates a significant positive relationship between social life and work, and work stress at a level of significance $(0.01)$.

Pearson coefficients were calculated between sample answers for the questionnaire according to the variables of the balance between social life and work and the variables of work stress as shown in the following table: 
International Journal of Data Mining \& Knowledge Management Process (IJDKP) Vol.9, No.1, January 2019

Table 10: The significant between the variables of the balance between social life and work, and the variables of work stress according to Pearson coefficients

\begin{tabular}{|c|c|c|c|}
\hline Variable & Work environment & Work Nature & $\begin{array}{c}\text { Roles } \\
\text { Conflict }\end{array}$ \\
\hline Personal and social dimension & $0.541^{* *}$ & $0.533^{* *}$ & $0.539^{* *}$ \\
\hline Psychological and behavioral dimension & $0.449^{* *}$ & $0.4662^{* *}$ & $0.457^{* *}$ \\
\hline Professional dimension & $0.542^{* *}$ & $0.527^{* *}$ & $0.564^{* *}$ \\
\hline Economic dimension & $0.458^{* *}$ & $0.443^{* *}$ & $0.434^{* *}$ \\
\hline
\end{tabular}

** Level of significance $(0.01)$.

Table (10) shows:

$\checkmark$ There is a medium positive correlation between the personal and social dimension of the balance between social life and work and the dimensions of work stress (work environment, work nature and roles conflicts)

$\checkmark$ There is a weak correlation between the psychological and behavioral dimension for the balance between social life and work and the dimensions of work stress(work environment, work nature and roles conflict).

$\checkmark$ There is a positive medium correlation between the professional dimension of the balance between social life and work and the dimensions of work stress (work environment, work nature and roles conflicts)

$\checkmark$ There is a weak correlation between the economic dimension of the balance between social life and work and the dimensions of work stress (work environment, work nature and roles conflict).

\section{Concluding Comments}

There is a medium level of balance between social life and work in the Ministry of Youth and Sports Affairs in the Kingdom of Bahrain. Also, there is a high degree of work pressure in the ministry which is due to the big role for the ministry in the society and its activated participation in most youth activities and events in different fields. This indicates that this kind of pressure is positive and motivates employees providing them with trust and feeling of accomplishments. Also, the highest application of balance between social life and work is represented in employee's abilities in organizing their family responsibilities and their abilities to separate between their professional life and luxury practices adequately. Furthermore, the least application of balance between social life and work is represented in employees lack of regulation of the entertainment journeys for their families, then lack of interest for athletic activities that keeps them healthy and this is due to the frequent business of the employees in accomplishing their professional tasks and lack of time for the entertainment and sports programmers. Employees see that their commitment relating to the professional rules resulted in improving their professional performance and increasing their productivity. Also, they agree that there is an equality in their salaries in all the departments of the ministry. The highest work pressure is represented in employee's priorities for the works and the inconvenient work environment to the nature of their works. The least work pressure is represented in employee's accomplishment of the tasks specified for them and correcting their mistakes while working. Employees have some difficulties in dealing with more than team work at a time Employees suffer from lack of light in their work environment. There is a medium correlation between personal and social dimension for the balance between social life and work, and work pressure variables (work environment, work nature and roles conflict). 
International Journal of Data Mining \& Knowledge Management Process (IJDKP) Vol.9, No.1, January 2019

Thereis also a weak correlation between psychological and behavioral dimension for the balance between social life and work, and work pressure variables (work environment work nature and roles conflict). Furthermore, there is a medium correlation between social dimension for the balance between social life and work, and work pressure variable (work environment, work nature and roles conflict). There is a weak correlation between the economic dimension for the balance between social life and work, and work pressure variables (work environment, work nature and roles conflict).

\section{REFERENCES}

[1] Abdeldayem Marwan M and Saeed Hameed Aldulaimi (2018) "The Economic Islamicity Index, between Islamicity and Universality: Critical Review and Discussion". International Business Management, Vol. (12), Pp. 46-52.

[2] Abdeldayem Marwan M (2018) "Teaching Philosophy and Learning Support in Higher Education as inspired from the Senior Fellowship of the Higher Education Academy, UK: A Case Study from Bahrain" Social Science Learning Education Journal, Vol. (3), No. (6), Pp. 77-84.

[3] Abdullatif, Rashad Ahmed (2010). Management of social associations, Dar Al Wafaa Press, Alexadira, Egypt.

[4] Al Bader, Ibrahim Bin Hamad (2010). "Organizational development and its link to work stress, empirical study, civil deference, Riyad" unpublished master, Arab Nayef University for security sciences, Riyad.

[5] Al Bagdadi, Adel, Hadi, Al Abbadi (2010). Organizational learning and organization and their relation to recent managerial concepts, Dar Al Waraq Press, Amman, Jordon.

[6] Al Bayati, Faris Rashed (2011). Performance accounting in developing the organizations and human resources, Dar Al Waraq Press, Amman, Jordon.

[7] Al Dawi, Khalid (2010). An approach in organizational development and methods of dealing with resistance, unpolished master, Aswan Universi

[8] Aldulaimi Saeed H and Abdeldayem Marwan M (2018), "The Economic Value of Time in Arab Culture: New Evidence using Zimbardo Time Perspective Inventory (ZTPI)", American Journal of Social Sciences and Humanities, Vol. (3), No. (1), Pp. 63-72

[9] Al Ghalbi, Taher Mohsen, Saleh, Ahmed Ali (2010). Organizational development, analytical approach, first edition, Dar Wael Press, Amman, Jordon.

[10] Al Maghrebi, Kamel Mohamed (2010). Organizational Behaviour, Dar Al Feker Press, Amman, Jordon.

[11] Al Meshaan, Soltan (2010). Sources of stress at work, a comparative study between Kuwaiti and nonKuwaiti employees in the public sector, King Saud University Journal, 22 (3).

[12] Al Qahtani, Saeed (2011). Reasons for work stress and how to deal with them, empirical study on King Khalid International Airport Customs, Riyad, Public Management Institute, Riyad, Saudi Arabia.

[13] Al Qtaish, Hasan Fleih (2011). Developing of Accounting System for Evaluating performance In The Public Sector, Jordanian Journal in Business Administration 7 (1).

[14] Al Sairafi, Mohamed (2010). Organizational Development, Dar Al Keker Press, Alexandria, Egypt.

[15] Al Sakran, Nasser Mohamed Ibrahim (2010). Organizational development and its effect on professional performance, empirical study on security officer employees in Riyad, unpublished master, Business Administration Department, Arab Nayef University for Security Science, Riyad, Saudi Arabia. 
International Journal of Data Mining \& Knowledge Management Process (IJDKP) Vol.9, No.1, January 2019

[16] Al Sebaie, Haniya (2010). Levels and sources of work stress of Saudi employees (females) in Saudi universities, Umm Al Qora University, Saudi Arabia.

[17] Al Shanty, Mahmood Abdelrahman Ibrahim (2010). The effect of organizational development on human resources performance, empirical study on the Palestinian ministries in Ghazza, unpublished master, Islamic University, Ghazza.

[18] Al tamimi, Fawaz, Ahmed Al Khateeb (2011). Total Quality Management and ISO (9001) requirements, second edition, Books world press, Erbed, Jordon.

[19] Amer, Sameh Abdelmotaleb (2011). Human resources strategies, Dar Al Feker Press, Amman, Jordon.

[20] Andraoes, Maiaa, Rami Jamal (2010). Management by trust and empowerment, Modern books world press, Amman, Jordon.

[21] Aalah, Mahmood Yousif (2010). Mnagement of International Associations, Dar Al Bedaia Press, Amman, Jordon.

[22] Asfoor, Mohamed Shaker (2010). Methods ad Principles of Organization, Dar Al Maseera Press, Amman, Jordon.

[23] Askar, Sameer Ahmed (2010). Work stress variables, an empirical study in the sector of banks, United Arab Emirates, Public Management, Riyad.

[24] Bahar, Yousif, Ayman (2010). Creativity and organizational change in modern organizations, unpublished master, Cairo University.

[25] Clark, S.C. (2001). Work family border theory: A new theory of work / life balance. Human Relations, 53 (6).

[26] Dodwee, Ahmed Yousif (2010). Management of change and organizational development, Dar Al Bazi Press, Amman, Jordan.

[27] Ghoneim, Ahmed Mohamed (2010). Total Quality Management, Modern Library press, Al Mansoora, Egypt.

[28] Hill, Peter (2001). What principles needed to know about teaching and learning in IAR TV Seminar Series: March 2001 No. 101.

[29] Ibrahim, Abou Al Hassan (2010). Managerial development in social care organizations. Modern office, Aswan, Egypt.

[30] Ismail, Mohamed Ahmed (2012). Work stress: Human Resources Forum, Cairo, Egypt.

[31] Jooda, Mahfooz Ahmed (2010). Total Quality Management, fourth edition, Dar Wael Press, Amman, Jordon.

[32] Kallaith, T., Brough, P., \& Poelmans, S. (2008). Achieving work - life balance: Current theoretical and practice issues. Journal of Management \& Organizations 14 (3).

[33] Kirchmeyer, C. (2001). Work-life balance initiatives: Greed or benevolence regarding workers' time, Trends in organizational behavior, Vol.7.

[34] Maher, Ahmed (2010). Organizations development, University House, Alexandria, Egypt.

[35] Nesairat, Fareed (2010). Total Quality Management and Organizational Performance, an exploratory study for administrators opinions in some private sector hospital, Amman, Jordon, Managerial Sciences studies, 34 (2).

[36] Voydanoff, P. (2008). Towards a conceptualization of perceived work-family fit and balance: A demands and resources approach. Journal of Marriage and family, 67. 